\title{
Transplacental transmission of torque teno virus
}

\author{
Elena A. Tyschik', Sophia M. Shcherbakova², Ruslan R. Ibragimov ${ }^{1}$ and Denis V. Rebrikov ${ }^{1,2^{*}}$
}

\begin{abstract}
Background: TTV has been detected in almost every human tissue type or body fluid reaching near 100\% prevalence. Several studies report mother-to-child postnatal transmission of TTV in infancy but the risk of transplacental transmission of TTV is still unclear.

Methods: The blood and plasma collected postpartum from 100 mother-child pairs were analyzed using TTV-specific qPCR. Samples were collected from the peripheral vein of the mother and the umbilical cord.

Results: Eighty four percent of pregnant women were TTV positive (median titers: $8 \times 10^{4}$ copies $/ \mathrm{mL}$; range: $10^{3}$ $3 \times 10^{7}$ ). The TTV load in plasma was approximately 100 times lower than in whole blood. TTV was not detected in any of cord blood samples.

Conclusions: Our data demonstrate the lack of transplacental transmission of TTV (or effective prenatal inhibition of viral proliferation). The presence of the virus in infants may be associated with mother-to-child transmission through breast feeding or other routes of transmission.
\end{abstract}

Keywords: Torque Teno Virus, Transfusion transmitted virus, TV, Transplacental transmission, Cord blood, Mother-to-child

\section{Background}

Torque teno virus (TTV) is a small virus of the Anelloviridae family with a circular ssDNA genome of negative polarity; it was first reported in 1997 in Japanese patients with non-A-G posttransfusion hepatitis [1]. TTV has been detected in almost every human tissue type or body fluid reaching near $100 \%$ prevalence [2, 3]; the virus is thought to be transmitted through breast feeding, by fecal-oral, respiratory, or sexual routes, through contaminated water, etc. [4]. Cross-species swine-to-human transmission of TTVs has also been reported [5]. Some data suggest TTV plasma load association with age and gender [6].

Mother-to-child transmission of viral infections can be transplacental, perinatal (through vaginal fluids or blood), or postnatal (through breast feeding or other routes). Transplacental transmission has been demonstrated for many viruses including the rubella virus, cytomegalovirus (CMV), herpes simplex virus (HSV), parvovirus B19

\footnotetext{
* Correspondence: ncagip4@gmail.com

1 Kulakov Research Center for Obstetrics, Gynecology and Perinatology,

1179970 parina 4, Moscow, Russia

${ }^{2}$ Pirogov Russian National Research Medical University, 1179970 strovityanova

1, Moscow, Russia
}

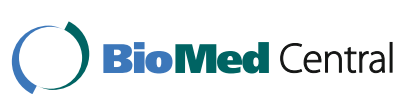

(c) The Author(s). 2017 Open Access This article is distributed under the terms of the Creative Commons Attribution 4.0 International License (http://creativecommons.org/licenses/by/4.0/), which permits unrestricted use, distribution, and reproduction in any medium, provided you give appropriate credit to the original author(s) and the source, provide a link to the Creative Commons license, and indicate if changes were made. The Creative Commons Public Domain Dedication waiver (http://creativecommons.org/publicdomain/zero/1.0/) applies to the data made available in this article, unless otherwise stated.

\section{Methods}

Ethical approval

The study protocol was reviewed and approved by the Ethics Committee of the Pirogov Russian National Research Medical University (Protocol No.2016/64); the study was conducted in accordance with the Declaration of Helsinki. All participants gave written informed consent. Blood samples obtained from the blood bank were anonymous.

(B19V), varicella-zoster virus (VZV), West Nile virus, measles virus, hepatitis $\mathrm{E}$ virus, human immunodeficiency virus (HIV), lymphocytic choriomeningitis virus (LCMV), .

Several studies report mother-to-child postnatal transplacental transmission of TTV is still unclear. The aim of this study was to quantify TTV in the venous blood and plasma of pregnant women and in the umbilical cord blood and plasma collected postpartum to estimate the possibility of transplacental transmission of TTV. 


\section{Blood samples collection}

Blood and plasma samples were collected from 100 mother-child pairs over the period from January to November 2016 at Kulakov Research Center for Obstetrics, Gynecology and Perinatology (Moscow, Russia). Mothers' ages ranged from 20 to 47, with mean age of 31 years. The inclusion criterion was normal singleton pregnancy. The exclusion criteria were as follows: pregnancy complications of any type, premature delivery, multiple pregnancies, and caesarean section. Two separate aliquots of each sample collected postpartum from a peripheral vein of the mother and the umbilical cord were placed into 4 mL EDTA Vacutainers. All samples were stored at $+4{ }^{\circ} \mathrm{C}$ for less than three hours before they were centrifuged for plasma separation first at $800 \mathrm{~g}$ for $5 \mathrm{~min}$ and then at $3000 \mathrm{~g}$ for $5 \mathrm{~min}$. Then whole blood and plasma were immediately frozen at $-80{ }^{\circ} \mathrm{C}$ until DNA extraction.

\section{DNA extraction}

DNA was extracted from $200 \mu \mathrm{l}$ aliquots of thawed whole blood or plasma using a standard commercial silica-sorbent kit for DNA extraction from body fluids (Probe-GS DNA Extraction Kit, DNA-Technology, Russia). To prevent exogenous contamination, DNA isolation was performed in a separate DNA extraction room (Zone 1). To prevent crosscontamination of the samples, all procedures were carried out in the UV-equipped PCR-box using sterile disposable tubes and aerosol-resistant tips.

\section{TTV quantification}

qPCR was performed using the DTprime Real-Time PCR Cycler (DNA-Technology, Russia) as described in [2], with test sensitivity of about 1000 viral copies per milliliter of blood/plasma. qPCR of the unique human genome fragment was used as DNA extraction control (in a separate PCR tube). To prevent PCR contamination by previous reactions or biological samples, the reactions were combined using aerosol-resistant tips in UV-equipped PCR-box in a separate PCR-preparation room (Zone 2). Also, no electrophoresis of TTV PCR products or other procedures that would require PCR-tube opening were performed in the building. All the negative controls and surface washings were negative.

\section{Data analysis}

qPCR data were analyzed using the DTprime Real-Time PCR Cycler Software v.7.7 (DNA-Technology, Russia). Microsoft Office Excel (Microsoft Corporation, USA) and Statistica 8.0 (StatSoft, USA) were used for statistical analysis.

\section{Results}

We have demonstrated that in $84 \%$ of pregnant women the TTV viral load is higher than $10^{3}$ copies per milliliter of whole blood (test sensitivity), with a maximum of $3 \times 10^{7}$ and a median of $8 \times 10^{4}$ viral genomes per $1 \mathrm{~mL}$ (see Fig. 1).

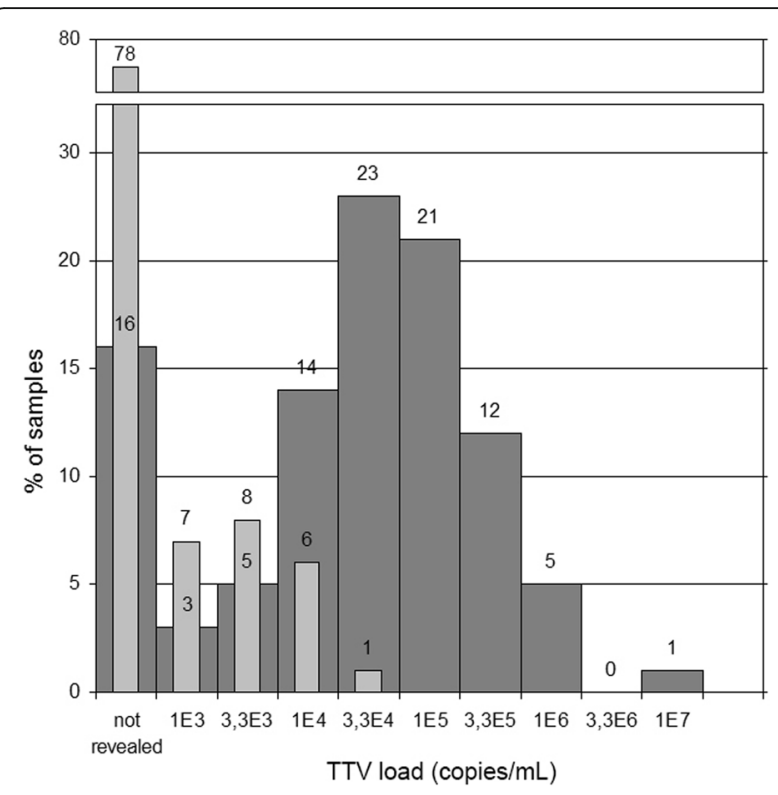

Fig. 1 TTV viral load in maternal samples (dark bars represent whole blood samples, light bars - plasma samples). Numbers above each bar represent the number of samples

The TTV load in plasma was approximately 100 times lower than in whole blood (22 samples were positive, with a maximum of $7 \times 10^{4}$ copies $/ \mathrm{mL}$ ) indicating the predominantly cellular localization of the virus.

TTV was not detected in any of cord blood samples. The levels of human genomic DNA were pretty similar in maternal and cord blood samples (an average of 4.1 and $4.2 \times 10^{8}$ copies $/ \mathrm{mL}$, respectively).

\section{Discussion}

The revealed presence of TTV in the venous blood of $84 \%$ of pregnant women correlates well with the previously published studies on healthy human populations $[2,6]$. Because of test sensitivity, only $22 \%$ of plasma samples came out positive for TTV. The TTV load in plasma was approximately 100 times lower than in whole blood. The PCR assay we used has sensitivity of about $10^{3}$ viral genomes per milliliter. Therefore, all samples with a lower viral load were considered negative. In [6] the authors detected TTV in $76 \%$ of plasma samples with test sensitivity of $10^{2}$ copies $/ \mathrm{mL}$. Based on the fact that the ratio of genomic DNA in the cells and extracellular fraction is about 1000 , we can assume that the virus found in plasma mostly comes from disrupted cells.

This study revealed an approximately 10-fold decline in the median value of the TTV load in whole blood samples compared to the results we obtained from elite athletes in our previous work [2]. This can be explained by changes in the DNA extraction technique, qPCR data analysis algorithm, or initial biological difference of analyzed groups. 


\section{Conclusions}

The TTV viral load of more than 1000 copies per $1 \mathrm{~mL}$ of whole blood was detected in $84 \%$ of pregnant women (with a maximum of $3 \times 10^{7}$ and a median of $8 \times 10^{4}$ copies $/ \mathrm{mL}$ ). The TTV load in plasma was approximately 100 times lower than in whole blood indicating the predominantly intracellular localization of the virus.

Our data demonstrate the lack of transplacental transmission of TTV. The presence of the virus in infants may be associated with mother-to-child transmission through breast feeding or other routes of transmission.

\section{Abbreviations}

PCR: Polymerase chain reaction; qPCR: Quantitative polymerase chain reaction; ssDNA: Single stranded deoxyribonucleic acid; TTV: Torque Teno Virus; UV: Ultraviolet

\section{Acknowledgements}

Not applicable.

\section{Availability of data and materials}

Not applicable.

\section{Competing interests}

The authors declare that they have no competing interests.

\section{Authors' contributions}

EAT and SMS conducted molecular studies, RRI performed the sampling, DVR designed the study, conducted the experiments and drafted the manuscript. All authors read and approved the final version of the manuscript.

\section{Consent for publication}

Not applicable.

\section{Ethical approval and consent to participate}

The study protocol was reviewed and approved by the Ethics Committee of the Pirogov Russian National Research Medical University (Protocol No.2016/ 64); the study was conducted in accordance with the Declaration of Helsinki. All participants gave written informed consent. Blood samples obtained from the blood bank were anonymous.

\section{Publisher's Note}

Springer Nature remains neutral with regard to jurisdictional claims in published maps and institutional affiliations.

Received: 28 February 2017 Accepted: 2 May 2017

Published online: 08 May 2017

\section{References}

1. Nishizawa T, Okamoto H, Konishi K, Yoshizawa H, Miyakawa Y, Mayumi M. A novel DNA virus (TTV) associated with elevated transaminase levels in posttransfusion hepatitis of unknown etiology. Biochem Biophys Res Commun. 1997:241:92-7.

2. Vasilyev EV, Trofimov DY, Tonevitsky AG, llinsky W, Korostin DO, Rebrikov DV. Torque Teno Virus (TTV) distribution in healthy Russian population. Virol J. 2009. doi:10.1186/1743-422X-6-134.

3. AbuOdeh R, Al-Mawlawi N, Al-Qahtani AA, Bohol MF, Al-Ahdal MN, Hasan HA, AbuOdeh L, Nasrallah GK. Detection and genotyping of torque teno virus (TTV) in healthy blood donors and patients infected with HBV or HCV in Qatar. J Med Virol. 2015. doi:10.1002/jmv.24146.

4. Bostan N, Nabgha-E-Amen, Bokhari H. Current and Future Prospects of Torque Teno Virus. J Vaccines Vaccin. 2013. doi:10.4172/2157-7560.S1-004

5. Ssemadaali MA, Effertz K, Singh P, Kolyvushko O, Ramamoorthy S. Identification of heterologous Torque Teno Viruses in humans and swine. Sci Rep. 2016. doi:10.1038/srep26655.

6. Haloschan M, Bettesch R, Görzer I, Weseslindtner L, Kundi M, PuchhammerStöckl E. TTV DNA plasma load and its association with age, gender, and
HCMV lgG serostatus in healthy adults. Age (Dordr). 2014. doi:10.1007/ s11357-014-9716-2.

7. Marino T, Smith SE, Marinez JE, Laartz B, Gompf SG. Viral Infections and Pregnancy. In: Medscape. 2014. http://emedicine.medscape.com/article/ 235213-overview. Accessed 03 Dec 2014.

8. Gerner P, Oettinger R, Gerner W, Falbrede J, Wirth S. Mother-to-infant transmission of TT virus: prevalence, extent and mechanism of vertical transmission. Pediatr Infect Dis J. 2000;19:1074-7.

9. Kazi A, Miyata H, Kurokawa K, Khan MA, Kamahora T, Katamine S, Hino S. High frequency of postnatal transmission of $T$ virus in infancy. Arch Virol. 2000;145:535-40.

10. Bagaglio S, Sitia G, Prati D, Cella D, Hasson H, Novati R, Lazzarin A, Morsica G. Mother-to-child transmission of TT virus: sequence analysis of non-coding region of TT virus in infected mother-infant pairs. Arch Virol. 2002;147:803-12.

11. Ohto H, Ujiie N, Takeuchi C, Sato A, Hayashi A, Ishiko H, Nishizawa T. Okamoto $\mathrm{H}$; vertical transmission of hepatitis viruses collaborative study group. TT virus infection during childhood. Transfusion. 2002;42:892-8.

12. Lin HH, Kao JH, Lee PI, Chen DS. Early acquisition of TT virus in infants: possible minor role of maternal transmission. J Med Virol. 2002;66:285-90.

13. Xin X, Xiaoguang Z, Ninghu Z, Youtong L, Liumei X, Boping Z. Mother-toinfant vertical transmission of transfusion transmitted virus in South China. J Perinat Med. 2004:32:404-6.

14. Komatsu H, Inui A, Sogo T, Kuroda K, Tanaka T, Fujisawa T. TTV infection in children born to mothers infected with TTV but not with HBV, HCV, or HIV. J Med Virol. 2004;74:499-506.
Submit your next manuscript to BioMed Central and we will help you at every step:

- We accept pre-submission inquiries

- Our selector tool helps you to find the most relevant journal

- We provide round the clock customer support

- Convenient online submission

- Thorough peer review

- Inclusion in PubMed and all major indexing services

- Maximum visibility for your research

Submit your manuscript at www.biomedcentral.com/submit 